\title{
Chemical Control of Vegetative Growth of Mango Cvs.Dashahari, Langra, Chuasa and Fazri through Paclobutrazol Application
}

\author{
Ashok Kumar ${ }^{1 *}$, C.P. Singh ${ }^{2}$, 1.D.Bist ${ }^{3}$ \\ ${ }^{1}$ Professor, Uttaranchal college of Agriculture Science, Uttaranchal University, Dehradun-248007, U.K. India. \\ ${ }^{2}$ Professor, Department of Horticulture, G.B.P.U.A\&T-Pant Nagar, U.P., India. \\ ${ }^{3}$ Professor, Department of Horticulture, G.B.P.U.A\&T-Pant Nagar U.K. India
}

*Corresponding Author: Ashok Kumar, Professor, Uttaranchal college of Agriculture Science, Uttaranchal University, Dehradun-248007, U.K. India.

\begin{abstract}
Twenty year old mango cvs. Dashahari, Langra, Chuasa and Fazri growing in Horticulture Research Station Patharchatta of G.B. Pant University of Agriculture \& Technology, Pant Nagar treated with $0-5 \mathrm{~g}, 1.0 \mathrm{~g} / \mathrm{meter}$ canopy diameter of Paclobutrazol (applied to the soil drench on 15 September 1997 and 15 October 1998 with control). The biennial bearing is very serious problem in north, east and central Indian commercial cultivars, while most of the south Indian varieties bear regularly. Therefore, application of cultar is most widely studied in view of its high potential for controlling plant growth and development of fruit crops in general and mango production in particular. The persistence of cultar in orchard soil for a long time and its half-life varies with soil type and climatic conditions, which may severely affect the development of subsequent crops and moved rapidly between the shoot tips and basal nodes both in the acropetal and basipetal directions and persisted for several months. It inhibits gibberellins biosynthesis at kaurene stage and has proved to be reduction of vegetative growth, promising for flower initiation in shoot bud, giving early and profuse flowering, increases fruit yield and improving quality regularly in alternate bearing cultivars. Data's are collected with three months of interval of deffrent perameters of vegetaion. All rates of paclobutrazol reduced growths and number of leaves including tree perameters. Chemical used Paclobutrazol [(2RS, 3RS)-1-(4-chlorophenyl)-4, 4-dimethyle-2-(1, 2, 4 Triazol-1-yl)] pentan-3-ethanol.
\end{abstract}

Additional Indexes: Paclobutrazol (PBZ), precocious, Mango (Mangifera indica L.), Auxins (IAA), Gibberellins, Cytokinins and Plant Growth Regulator.

\section{INTRODUCTION}

Paclobutrazol [(2RS, 3RS)-1-(4-chlorophenyl)-4, 4-dimethyle-2- (1, 2, 4 Triazol-1-yl)] pentan-3ethanol, usually applied to the soil due to its low solubility and long residual activity. This group of growth retardants is most efficacious as it reduced shoot elongation and promote flowering as a result paclobutrazol is being promoted to control flowering and vegetative growth in commercial mango of Indo china. Australia and South Africa (Tongumpai et al. 1989; Rowley, 1990; Hillier and Rudge, 1991 and Voon et al.; 1991).

Paclobutrazol is very important Plant Growth Regulotors effecting various growth and development process of all plant spp. through inhibitors of Gibberellins biosynthesis, it is taken by xylem and translocated acropetatlay to sub-apical meristem, when persistent effect can provided. Paclobutrazol metabolized in plant within 10-15 days but persists in soil generally for more than one year (1-5 years), Gibberellins most likely $\mathrm{GA}^{1}$ are necessary for normal shoot elongation. Inhibition of bud breaks and shoots elongation in response to application of growth retardants chloremquate chloride (Maiti et al. 1972 a) and triazoles (Kulkarani, 1998 a; Burondkar and Gunjat, 1991, 1991. 1993: Tongumpai et al. 1991 a; Kulkarani et al., 1992: Winston, 1992:, Kurian and lyer 1993 a b; Nuneg Eligea et al., 1993). The Paclobutrazol is a triazole derivative and has been shown to inhibit shoot growth on apple trees (Coolbaugh et al.), Showed that ancymidol blocks with high specificity the oxidative steps leading from ent-kaurene to ent-kaurenoic acid in the pathway of GA' biosynthesis. The same oxidative steps are thought to be inhibited by the active triazol derivatives. Paclobutrazol has been reported to inhibit GA biosynthesis in plants by inhibiting kaurene oxidase, a Cyt P-450 oxidase, thus, blocking the oxidation of kaurene to kaurenoic acid. The inhibitory activity of paclobutrazol can be reversed by GA (QUINLAN JD, PJ RICHARDSON 1984). Paclobutrazol was 
also shown to shift assimilate partitioning from leaves to roots, increase carbohydrates in all parts of apple seedlings, increase Chlorophyll content, soluble protein, and mineral element concentration in leaf tissue, increase root respiration and reduce water use (Wang, S.Y., GL Stefence 1985).

\subsection{Gibberellins Skelton}

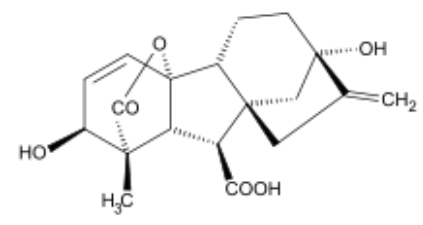

[Chemical formula of $\mathrm{GA} 3$ Molecular Mass $\left(\mathrm{C}_{19} \mathrm{H}_{22} \mathrm{O}_{6}\right) 346.37 \mathrm{~g} / \mathrm{mol}$ with melting point is 233 to $235^{\circ} \mathrm{C}(451$ to $455^{\circ} \mathrm{F}$; 506 to $508 \mathrm{~K}$ ) (decomposition)]

The term "gibberellins" was first used in 1935 to describe a substance produced by the fungus Gibberella fujikuroi that caused overgrowth symptoms in rice, which was termed the bakanae disease (Yabuta, 1935). This substance proved to be a mixture of GAs, with GA1 and GA3 being the active factors (Takahashi et al., 1955). The early work on GAs remained undiscovered outside of Japan until after World War II, when there was an explosion of interest among plant physiologists and horticulturists. P.W. Brian, working at the Imperial Chemical Industries' Akers Laboratories in the United Kingdom, induced dwarf pea plants to elongate as normal, tall plants by applying GA3, which he obtained from cultures of G. fujikuroi (Brian and Hemming, 1955). On the basis of these experiments, he proposed that GA was the natural growth factor that was deficient in the dwarf plants. This hypothesis was confirmed by Margaret Radley from the same laboratory, who reported that purified extracts from tall pea seedlings induced stem elongation in dwarf peas, thereby providing evidence that GAs were indeed naturally occurring in higher plants (Radley, 1956).

Similar experiments were carried out in B.O. Phinney's laboratory at the University of California, Los Angeles, where dwarf maize was used as a bioassay to show that many plant extracts contained substances with GA-like activity (Phinney et al., 1957).

\subsection{Biosynthesis of GA3}

GA3 is products of the diterpenoid pathway and their formation is initiated by cyclization of the common C20precursor GGPP. This intermediate is synthesized in plastids from isopentenyl diphosphate, shown recently to be formed in these organelles from glyceraldehydes 3phosphate and pyruvate rather than mevalonic acid, as was previously assumed (Lichtenthaler et al., 1997). However, it has not yet been demonstrated that GAs are products of the glyceraldehydes 3phosphate/pyruvate pathway. In growing vegetative tissues, the cyclization of GGPP occurs in proplastids and results in the formation of a hydrocarbon, ent-kaurene, in a two-step process requiring the activity of two enzymes: CPS, which produces the intermediate copalyl diphosphate, and entkaurene synthase.

GGPP is also the precursor of carotenoids and is incorporated into chlorophyll. These compounds are present at several orders of magnitude greater concentration than ent-kaurene and the GAs, so the first step on the GA pathway, catalyzed by CPS, needs to be tightly regulated. ent-Kaurene is converted to the bioactive GAs by a series of oxidative reactions catalyzed by two types of enzyme. The early reactions, resulting in contraction of ring $B$ from six to five $C$ atoms to give the GA structure, occur on extraplastidic membranes.

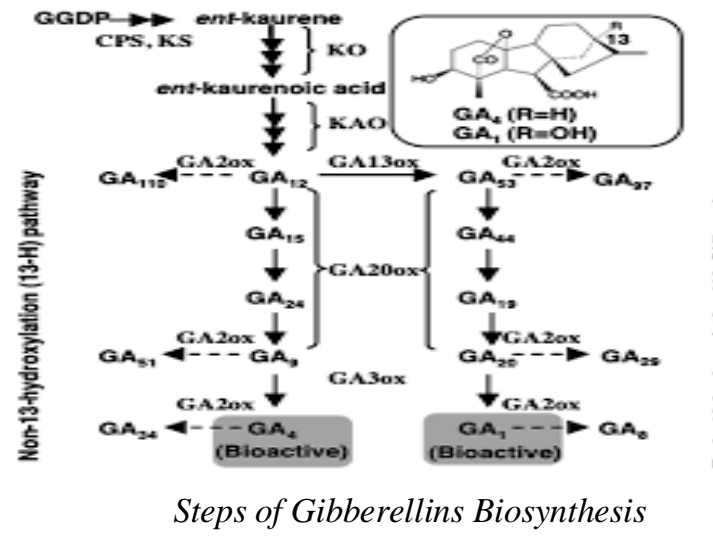




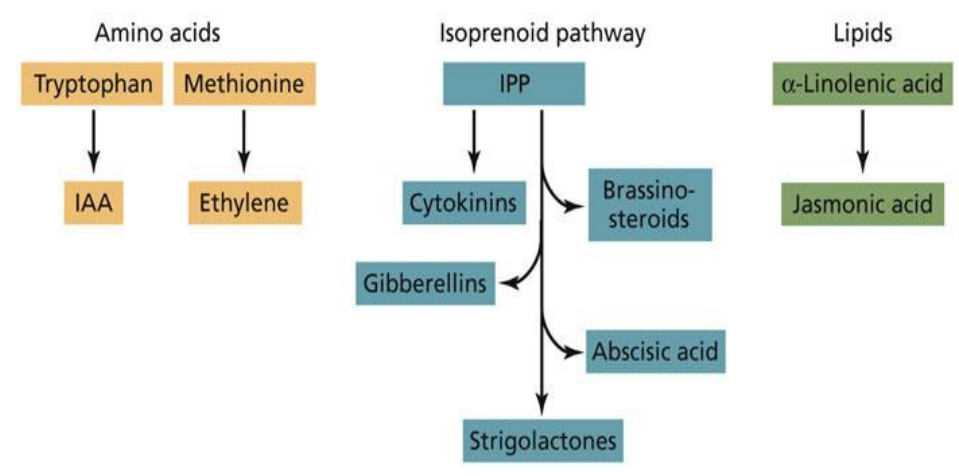

[Cytokinins, brassinosteroids, gibberellins, abscisic acid, and strigolactones. And finally, jasmonic acid is synthesized from a lipid precursor.]

This requires the movement of ent-kaurene out of the plastid by an as-yet-unknown mechanism. The reactions are catalyzed by Cyt P450-dependent monooxygenases and, in the shoot tissues of most plants, give rise to GA12 and its 13-hydroxylated analog GA53. These intermediates are metabolized further by soluble dioxygenases, which use 2-oxoglutaric acid as a cosubstrate. Two dioxygenases are required to convert GA12 and GA53 by parallel pathways to the bioactive products GA4 and GA1, respectively. First, GA 20-oxidase converts C-20 from a methyl group to an aldehyde and then removes the $\mathrm{C}$ atom to form the characteristic $\gamma$-lactone of the C19GAs. Second, a hydroxyl group is introduced at the $3 \beta$ position by a GA $3 \beta$-hydroxylase. A third 2-oxoglutarate-dependent dioxygenase that hydroxylates at the $2 \beta$ position inactivates the GA molecule and thus ensures turnover of the active forms. The pathways (MacMillan, 1997) and biochemistry/molecular biology (Hedden and Kamiya, 1997; Lange, 1998) of GA biosynthesis have been reviewed recently elsewhere.

Regulation of GA3 Biosynthesis: GAs mediates many developmental and environmental responses in plants. Consequently, regulation of GA biosynthesis is necessarily complex. The isolation of GAbiosynthetic genes has enabled direct analysis of their expression in terms of transcript abundance, allowing new insights into regulatory mechanisms. One such mechanism that plants use to maintain GA homeostasis (i.e. keeping the concentrations of bioactive GAs within certain limits) involves feedback regulation of GA biosynthesis, as illustrated in Figure 3. This effect was first observed in GA-response mutants, such as Rht3 in wheat, Dwarf8 in maize, and gai in Arabidopsis. Although they are dwarf mutan ts, they contain large amounts of bioactive GAs (for review, see Scott, 1990; Hedden and Kamiya, 1997).

In contrast, slender mutants such as the la cry s mutant of pea grow as if they were treated with large quantities of GA; however, they actually contain reduced amounts of active GAs (Martin et al., 1996). Paclobutrazol also prevented accumulation of water stress-induced -aminocyclopropane- -carboxylic acid, -(malonylaminocyclopropane- carboxylic acid, ethylene production and polyamines in apple leaves (Stichcombe, G.R.; E, Copas; R.R Williams', G Arnold 1984). Paclobutrazol has been applied to leaves (Williams, M.W; U. Edgerton, 1983), to roots or directly to the vascular system of the stems (Barrette, J.E; C.A, Bartuska, 1982). Sterrett (Stereett, J.P, 1985) found that $27 \mathrm{~d}$ after the pressure injection of ['4C] paclobutrazol into the trunk of young apple trees, $23 \%$ of the 14Cactivity was in the shoots, $1 \%$ was in the xylem and phloem tissue between the graft and apex; $58 \%$ remained in the xylem and phloem tissue near the injection site and $8 \%$ was in the roots.

The translocation of paclobutrazol from root uptake has been assumed to occur primarily through xylem (DALZIOL J, DK LAWRENCE 1984). However, few direct experimental data have been provided to support this assumption. The objectives of this study were to determine 'Abbreviations: GA, gibberellin; El, electron impact; TMSi, trimethylsilyl ether; amu, atomic mass unit. the translocation and distribution pattern of paclobutrazol from root system of apple seedlings at various time intervals by GC and to confirm the presence of paclobutrazol in apple seedling tissues by GCMS. MATERIALS AND METHODS Plant Material and Treatments. The growing conditions and treatments of the apple seedlings ('York Imperial' Malus domestica Borkh.) were as described previously $(15,19)$. Apple seeds were germinated in the greenhouse and grown in sand until approximately $10 \mathrm{~cm}$ in height. After washing sand from the roots, the seedlings were grown for 1 week in continuously aerated nutrient solution. The treatments were initiated by adding $34 \mathrm{gM}$ 
paclobutrazol (95\% active; ICI Americans, Inc.) in nutrient solution. For study of the possibility of basipetal paclobutrazol translocation to the root, leaves were dipped in 340 IM.

\section{Material AND Methods}

The experiments was conducted in sub-tropical climate of G. B. Pant University of Agriculture \& Technology- Pantnagar (India) using for 21-22 year old Mango Cvs. Dashehari, Langra, Chuasa and Fazri, planted at Horticulture Research Station, Patharchatta. The soil was black forest although $\mathrm{pH}$ was near 7.0 and base saturation laveld exceeded $70 \%$ and me in all the horizons $0-18 \mathrm{~cm}$ and $18-70$ $\mathrm{cm}$ respectvely (Mc Intosh, 1992), the trees were irrigated with ring system. The trees were treated with paclobutrazol (Cultur ICI, UK) once during the year at 15 September 1997 and 15 Oct. 1998. Treatments were (1) treated trees- control (2) Soil drench application $1.0 \mathrm{~g} /$ meter canopy diameter and $0.5 \mathrm{~g} /$ meter canopy diameter. Paclobutrazol was desolved in water and drench in basal of mango trees of Dashari, Langra, Chuasa and Fazri. Data were recorded for each tree and with periodical meanusenets of shoot extension of terminal branches were performed on 20 selected scaffold branches per tree during two years. Factorial randomized block design with 4 trees each treatment with 4 replication was used. All data's were subjected to analysis of variance (ANOVA) after analysis of two factorial RBD.

\section{RESULT AND DISCUSSION}

The discussed results suggest that soil drench of paclobutrazol meet the criteria set for this study. Paclobutrazol treatment on Mango cvs. Dashari, Langra, Chuasa and Fazri differed in thier growth in terms of tree height, tree growth diameter, tree circumference and tree canopy volume etc. early application were more effective in all the cultivars than the late application. There was latter difference between paclobutrazol treatments in cultivars which could be due is minor difference in tree height, crown diameter and circumference. In general varietal response to Paclobutrazol treatment was similar in all the cultivars. Data (1A, 1B \& 2A, 2B) suggested that Paclobutrazol reduced short length and number of leaves /shoots as reported by other workers in Mango (Wood, 1984; Kulkarani, 1998; Gougey, 1990: Khader, 1991; Kurian and lyer, 1993).

Data again suggested that Paclobutrazol treatment inhibited shoot elongation and reduced schoots length in mango cvs. Dashehari, Langra, Chausa and Fazri. The inhibition of shoot elongation was charectorized mainly by reduced intermodal length and although of number was reduced as well. As we reported for mango cultivars, leaf number were reduced is a lesser degree than short length of shoots to Paclobutrazol treated tree assumed a rossette- like appearance and area /leaf on the paclobutrazol shortened (datas not shown). On a per tree basis, leaf area and therefore probably photosynthitic capacity was reduced since chlorophyll in shoots and newly developed leaves was not increased by Paclobutrazol treatments. The experiment indicate that certain growth reduced physiological procees of large, mature mango cultivars are sensitive to Paclobutrazol and can retard shoot elongation by about $20 \%$ without mutch, if any loss in fruit production. Paclobutrazol doses producing greater inhibition of vegetative growth probably would reduce leaf area. A $20 \%$ reduced is shoot growth may not be enough is quality in the use as Paclobutrazol on large tree in commercial orchard system.

Table1A. Effect of Paclobutrazol treatments on vegetatative growth on mango cvs. Dashehari, Langra, Chusa and Fazli (1997-98)

\begin{tabular}{|c|c|c|c|c|c|c|c|c|c|c|c|c|c|c|c|c|c|c|}
\hline \multirow{3}{*}{$\begin{array}{c}\text { Treatme } \\
\text { nt }\end{array}$} & \multicolumn{3}{|c|}{$\begin{array}{l}\text { Length of } \\
\text { shoots }(\mathrm{cm})\end{array}$} & \multicolumn{3}{|c|}{$\begin{array}{l}\text { Diameter of } \\
\text { shoots }(\mathrm{cm})\end{array}$} & \multicolumn{3}{|c|}{$\begin{array}{c}\text { No of leaves } \\
\text { /shoots }\end{array}$} & \multicolumn{3}{|c|}{$\begin{array}{c}\text { Width of } \\
\text { leaves }(\mathrm{cm})\end{array}$} & \multicolumn{3}{|c|}{$\begin{array}{l}\text { Length of } \\
\text { shoots }(\mathrm{cm})\end{array}$} & \multicolumn{3}{|c|}{$\begin{array}{l}\text { Intermodal } \\
\text { length }(\mathrm{cm})\end{array}$} \\
\hline & $\begin{array}{c}15 \\
\text { Sept }\end{array}$ & $\begin{array}{c}15 \\
\text { June }\end{array}$ & $\begin{array}{c}\% \\
\text { increa }\end{array}$ & $\begin{array}{c}15 \\
\text { Sept }\end{array}$ & \begin{tabular}{|c|}
15 \\
Jun
\end{tabular} & $\%$ & $\begin{array}{c}15 \\
\text { Sept. }\end{array}$ & $\begin{array}{c}15 \\
\text { June }\end{array}$ & $\%$ & $\begin{array}{c}15 \\
\text { Sept }\end{array}$ & $\begin{array}{l}15 \\
\text { Jun }\end{array}$ & $\%$ & $\begin{array}{c}15 \\
\text { Sept }\end{array}$ & $\begin{array}{c}15 \\
\text { June }\end{array}$ & $\%$ & $\begin{array}{c}15 \\
\text { Sept }\end{array}$ & $\begin{array}{c}15 \text { June } \\
1999\end{array}$ & $\%$ \\
\hline & 1998 & 1999 & $\mathrm{e}$ & $\begin{array}{c}. \\
89 \\
8\end{array}$ & \begin{tabular}{|c|}
$\mathrm{e}$ \\
199 \\
9
\end{tabular} & $\mathrm{e}$ & 1998 & 1999 & $\mathrm{e}$ & $\begin{array}{c}199 \\
8\end{array}$ & $\begin{array}{c}\mathrm{e} \\
199 \\
9\end{array}$ & $\mathrm{e}$ & . & 1999 & e & $\begin{array}{c}199 \\
8\end{array}$ & & $\mathrm{e}$ \\
\hline $\begin{array}{l}\text { Dashehari } \\
\text { Control } \\
\text { 1.0g PBZ m }\end{array}$ & $\begin{array}{l}11.69 \\
1239\end{array}$ & $\begin{array}{l}11.92 \\
1252\end{array}$ & 2.13 & 0.68 & 0.70 & 2.94 & 9.42 & 9.54 & 1.81 & 4.59 & 4.72 & 2.83 & $\begin{array}{l}17.73 \\
1676\end{array}$ & $\begin{array}{l}17.98 \\
1684\end{array}$ & 1.14 & 2.97 & 2.97 & 6.83 \\
\hline $\begin{array}{l}\text { tree canopy } \\
\text { diam. }\end{array}$ & & 12.52 & 1.04 & 0.64 & 0.69 & 7.81 & $\begin{array}{c}11.5 \\
6\end{array}$ & $\begin{array}{c}11.6 \\
8\end{array}$ & 1.03 & 4.81 & 4.90 & 1.87 & & & 0.47 & 2.68 & 2.78 & 3.77 \\
\hline
\end{tabular}


Chemical Control of Vegetative Growth of Mango Cvs. Dashahari, Langra, Chuasa and Fazri through Paclobutrazol Application

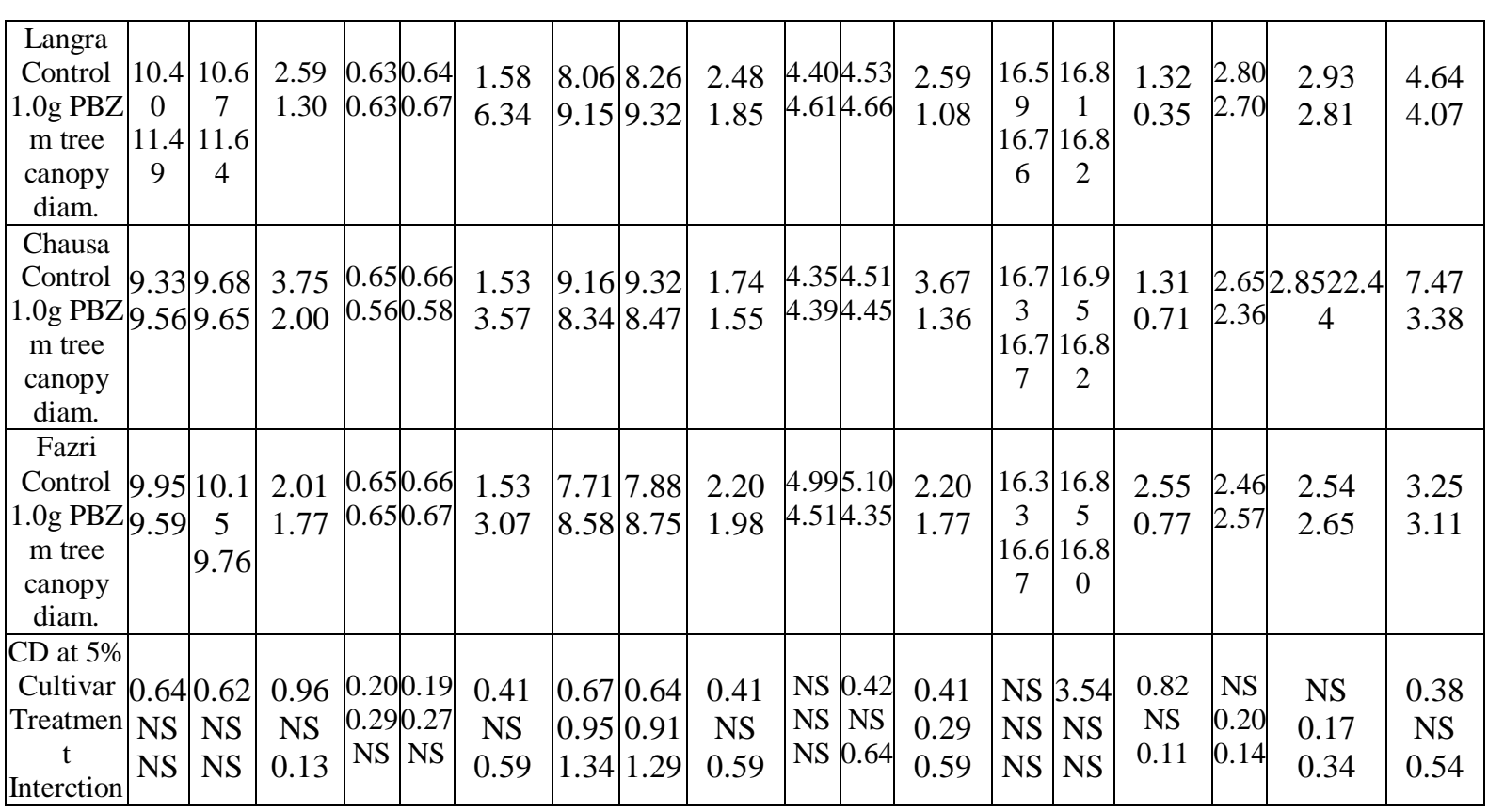

(Means followed by different letters within columns significantly differ by Fisher's LSD at $p=0.05$ )

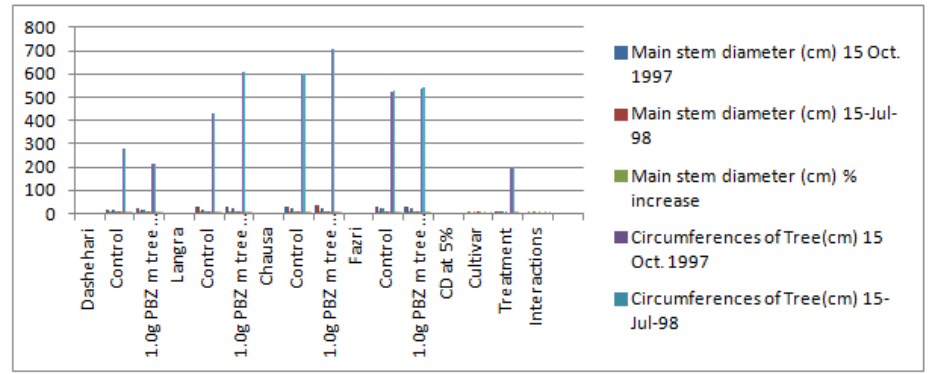

Fig1. Effect of Paclobutrazol treatments on vegetatative growth on mango cvs. Dashehari, Langra, Chusa and Fazli (1997-98)

Table1B. Effect of Paclobutrazol treatments on vegetatative growth on mango cvs. Dashehari, Langra, Chusa and Fazli (1997-98)

\begin{tabular}{|c|c|c|c|c|c|c|c|c|c|c|c|c|c|c|c|}
\hline \multirow[t]{2}{*}{ Treatment } & \multicolumn{3}{|c|}{$\begin{array}{c}\text { Main stem diameter } \\
(\mathrm{cm})\end{array}$} & \multicolumn{3}{|c|}{$\begin{array}{l}\text { Circumferences of } \\
\text { Tree }(\mathrm{cm})\end{array}$} & \multicolumn{3}{|c|}{$\begin{array}{c}\text { Tree crown } \\
\text { diameter(m) }\end{array}$} & \multicolumn{3}{|c|}{ Tree Volume } & \multicolumn{3}{|c|}{ Tree Height(m) } \\
\hline & \begin{tabular}{|c|}
15 \\
Oct. \\
1997 \\
\end{tabular} & \begin{tabular}{|c|}
15 \\
July \\
1998 \\
\end{tabular} & $\begin{array}{c}\% \\
\text { increase }\end{array}$ & \begin{tabular}{|c|}
15 \\
Oct. \\
1997 \\
\end{tabular} & \begin{tabular}{|c|}
15 \\
July \\
1998 \\
\end{tabular} & $\begin{array}{c}\% \\
\text { increase }\end{array}$ & $\begin{array}{c}15 \\
\text { Oct. } \\
1997\end{array}$ & \begin{tabular}{|c|}
15 \\
July \\
1998 \\
\end{tabular} & $\begin{array}{c}\% \\
\text { increase }\end{array}$ & $\begin{array}{c}15 \\
\text { Oct. } \\
1997 \\
\end{array}$ & \begin{tabular}{|c|}
15 \\
July \\
1998 \\
\end{tabular} & $\begin{array}{c}\% \\
\text { increase }\end{array}$ & $\begin{array}{c}15 \\
\text { Oct. } \\
1997\end{array}$ & \begin{tabular}{|c|}
15 \\
July \\
1998 \\
\end{tabular} & $\begin{array}{c}\% \\
\text { incre } \\
\text { ase }\end{array}$ \\
\hline $\begin{array}{c}\text { Dashehari } \\
\text { Control } \\
\text { 1.0g PBZ m tree } \\
\text { canopy diam. }\end{array}$ & $\begin{array}{l}18.57 \\
20.75 \\
\end{array}$ & $\begin{array}{l}19.20 \\
21.12\end{array}$ & $\begin{array}{l}1.74 \\
1.78\end{array}$ & $\begin{array}{l}16.34 \\
15.03\end{array}$ & $\begin{array}{l}16.77 \\
15.16\end{array}$ & $\begin{array}{l}2.63 \\
0.93\end{array}$ & $\begin{array}{l}5.27 \\
4.78\end{array}$ & $\begin{array}{l}5.35 \\
4.82\end{array}$ & $\begin{array}{l}1.51 \\
0.83\end{array}$ & $\begin{array}{l}276.45 \\
210.24\end{array}$ & $\begin{array}{l}279.45 \\
210.81\end{array} \mid$ & $\begin{array}{l}1.12 \\
0.27\end{array}$ & $\begin{array}{l}4.47 \\
4.60\end{array}$ & $\begin{array}{l}4.65 \\
4.67\end{array}$ & $\begin{array}{l}3.50 \\
1.52\end{array}$ \\
\hline $\begin{array}{c}\text { Langra } \\
\text { Control } \\
1.0 \mathrm{~g} \text { PBZ m tree } \\
\text { canopy diam. }\end{array}$ & $\begin{array}{l}30.12 \\
29.25\end{array}$ & $\begin{array}{l}30.49 \\
29.77\end{array}$ & $\begin{array}{l}1.22 \\
1.77\end{array}$ & $\begin{array}{l}19.12 \\
21.08\end{array}$ & $\begin{array}{l}19.38 \\
21.18\end{array} \mid$ & $\begin{array}{l}1.36 \\
0.47\end{array}$ & $\begin{array}{l}6.01 \\
6.71\end{array}$ & $\begin{array}{l}6.16 \\
6.77\end{array}$ & $\begin{array}{l}2.49 \\
0.89\end{array}$ & $\begin{array}{l}431.09 \\
606.15\end{array}$ & 433.16 & $\begin{array}{l}0.48 \\
0.11\end{array}$ & $\begin{array}{l}6.11 \\
6.16\end{array}$ & $\begin{array}{l}3.32 \\
6.26\end{array}$ & $\begin{array}{l}3.43 \\
1.62\end{array}$ \\
\hline $\begin{array}{c}\text { Chausa } \\
\text { Control } \\
1.0 \mathrm{~g} \text { PBZ m tree } \\
\text { canopy diam. }\end{array}$ & $\begin{array}{l}30.74 \\
33.00\end{array}$ & $\begin{array}{l}31.12 \\
33.80\end{array}$ & $\begin{array}{l}1.20 \\
2.42\end{array}$ & $\begin{array}{l}21.29 \\
24.50\end{array}$ & $\begin{array}{l}21.69 \\
24.60\end{array}$ & $\begin{array}{l}1.87 \\
0.41\end{array}$ & $\begin{array}{l}6.77 \\
6.16\end{array}$ & $\begin{array}{l}6.90 \\
7.24\end{array}$ & $\begin{array}{l}1.92 \\
1.12\end{array}$ & $\begin{array}{l}597.11 \\
707.91\end{array} \mid$ & $\begin{array}{l}600.23 \\
708.10\end{array}$ & $\begin{array}{l}0.52 \\
0.02\end{array}$ & $\begin{array}{l}7.47 \\
6.90\end{array}$ & $\begin{array}{l}7.64 \\
6.90\end{array}$ & $\begin{array}{l}2.27 \\
0.86\end{array}$ \\
\hline $\begin{array}{c}\text { Fazri } \\
\text { Control } \\
\text { 1.0g PBZ m } \\
\text { tree canopy } \\
\text { diam. }\end{array}$ & $\begin{array}{l}29.50 \\
31.50\end{array}$ & $\begin{array}{l}29.83 \\
32.40\end{array}$ & $\begin{array}{l}1.11 \\
2.85\end{array}$ & $\begin{array}{l}20.01 \\
19.65\end{array}$ & $\begin{array}{l}20.31 \\
19.73\end{array} \mid$ & $\begin{array}{l}1.49 \\
0.41\end{array}$ & $\begin{array}{l}6.40 \\
6.76\end{array}$ & $\begin{array}{l}6.54 \\
6.84\end{array}$ & $\begin{array}{l}2.18 \\
1.18\end{array}$ & $\begin{array}{l}521.47 \\
538.15\end{array}$ & $\begin{array}{l}528.33 \\
539.00\end{array}$ & $\begin{array}{l}1.31 \\
0.15\end{array}$ & $\begin{array}{l}6.27 \\
6.89\end{array}$ & \begin{tabular}{|l|}
6.57 \\
6.98
\end{tabular} & $\begin{array}{l}4.78 \\
1.30\end{array}$ \\
\hline $\begin{array}{l}\text { CD at 5\% } \\
\text { Cultivar } \\
\text { Treatment } \\
\text { Interactions }\end{array}$ & $\begin{array}{c}\text { NS } \\
3.77 \\
\text { NS }\end{array}$ & $\begin{array}{l}\mathrm{NS} \\
3.88 \\
\mathrm{NS}\end{array}$ & $\begin{array}{l}0.67 \\
0.47 \\
0.95\end{array}$ & $\begin{array}{l}\mathrm{NS} \\
2.63 \\
\mathrm{NS}\end{array}$ & $\begin{array}{c}\mathrm{NS} \\
2.78 \\
\mathrm{NS}\end{array}$ & $\begin{array}{l}0.84 \\
\mathrm{NS} \\
0.59\end{array}$ & $\begin{array}{l}\text { NS } \\
0.76 \\
\text { NS }\end{array}$ & $\begin{array}{l}1.07 \\
\mathrm{NS} \\
\mathrm{NS}\end{array}$ & $\begin{array}{l}0.75 \\
\text { NS } \\
0.10\end{array}$ & $\begin{array}{c}\text { NS } \\
191.56 \\
\text { NS }\end{array}$ & $\mid \begin{array}{c}\text { NS } \\
200.54 \\
\text { NS }\end{array}$ & $\begin{array}{l}0.46 \\
0.32 \\
0.65\end{array}$ & $\begin{array}{l}\text { NS } \\
0.55 \\
\text { NS }\end{array}$ & \begin{tabular}{|c|} 
NS \\
0.59 \\
NS
\end{tabular} & $\begin{array}{c}0.14 \\
\text { NS } \\
0.20\end{array}$ \\
\hline
\end{tabular}

(Means followed by different letters within columns significantly differ by Fisher's LSD at $p=0.05$ ) 


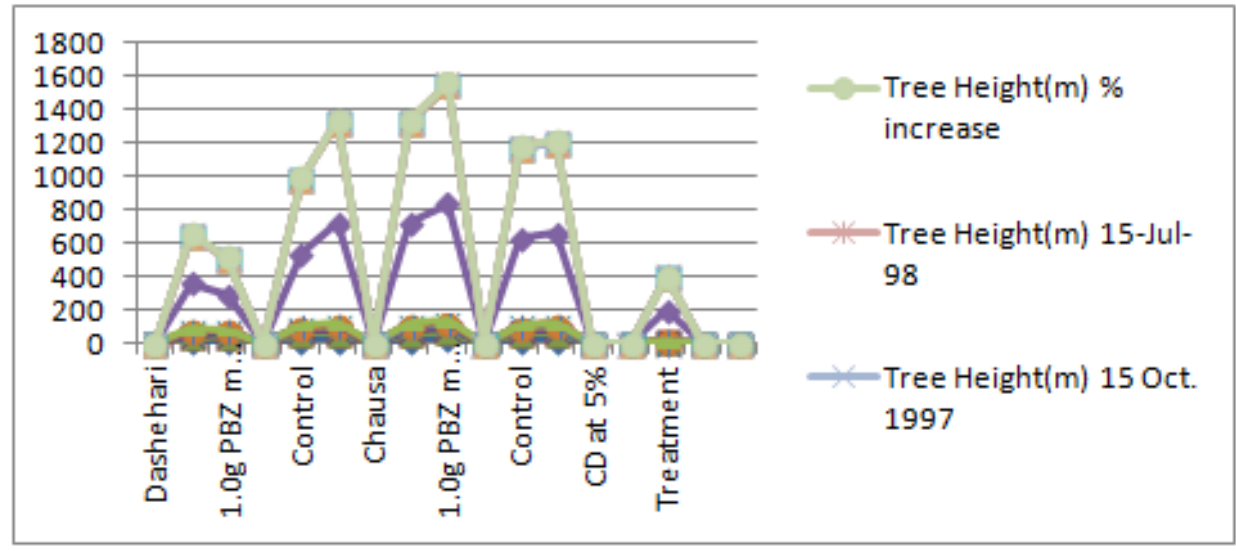

Fig1A. Effect of Paclobutrazol treatments on vegetatative growth on mango cvs. Dashehari, Langra, ChusaandFazli (1997-98)

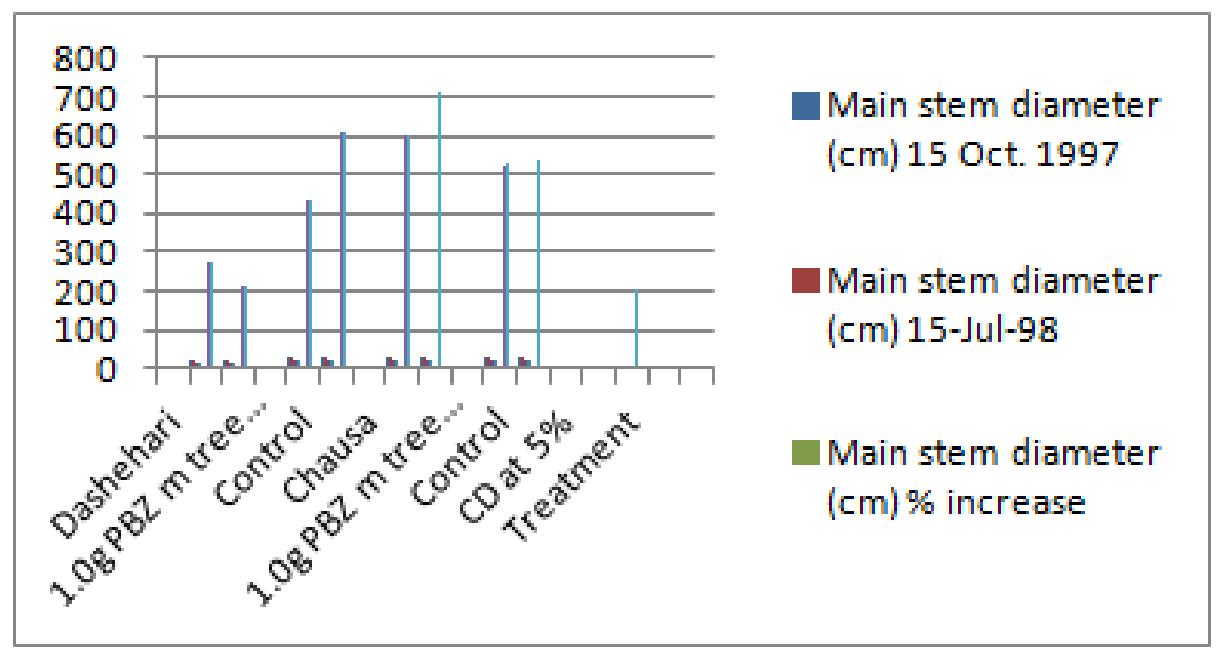

Fig1B. Effect of Paclobutrazol treatments on vegetatative growth on mango cvs. Dashehari, Langra, Chusa and Fazli (1997-98)

It may have application however, if used in commercial with pruning when regrowth after pruning might sufficiant increase in shoot growth and area to offset the Paclobutrazol induced loss of shoot growth and area. This approch might help offset any yield to loss from using Paclobutrazol alone but has not yet been demonstrated.

Cloning the genes of the GA-biosynthetic pathway is opening a wide range of research opportunities in plant biology. ThisUpdate highlights the rapid progress in exciting but preliminary studies of how GA mediates developmental and environmental effects on growth. This progress is also providing new information on the sites of GA biosynthesis and on the function and structures of the biosynthetic enzymes, allowing genetic manipulation of specific steps in the pathways of transgenic plants. Furthermore, it has finally been possible to establish the molecular basis for many of the mutations that affect plant stature, some of which have been known for many years and are an important component of several crop varieties.

Soil application of Paclobutrazol in exsess in of $1.0 \mathrm{~g} / \mathrm{mt}$. canopy diameter cover had Residual effect or tree growth for 2-3 year after application. Soil application of less than $1.0 \mathrm{~g} / \mathrm{mt}$ canopy diameter cover delayed vegetative growth after the following harvest by 1-2 months compared with untreated trees. So there fore we concluded that's paclobutrazol restricted vegetative flushing in mango cvs. Dashahari, Langra, Chuasa and Fazri due is block of O2 (Oxygen) inbetween kaurene and entkaurene of gibberellins biosynthesis.

\section{ACKNOWLEDGEMENT}

I take this opportunity to express my sincere thanks, profound sense of severance and gratitude to late Dr. Sant Ram. Prof. And Dean PGS and Chairman my advisor committee for his valuable guidence 


\section{Literature Cited}

[1] Allan, P.: George, A.P.; Nissen, R.J.; Rasmussen, T.S. and Morley Bunker, M.J. $1993 . \quad$ Effect of Paclobutrazol on phonological cycling of low chill Florida prince' Peach in Subtropical Australia. Scientia Hortic., 53:73-84.

[2] Byun, J.K. and chang. K.H. 1986. Influence of Paclobutrazol on Carbohydrate, Mineral Nutrition and fruit quality of Fuji Apple tress. J. Korean Soci. Hort. Sci, 27:331-337.

[3] Brian PW, Hemming HG, 1955. The effect of gibberellic acid on shoot growth and development. Physiol Plant. 8:669-681

[4] Chandel, J.S. and Jindal, K.K. 1991. Effect of Triacontanol (TRIA) and Paclobutrazole on fruit set, yield and quality of Japanese plum. Hort. J, 4: 21-25.

[5] Choi, J.S.; Shin, K.C.; Kim, J.K; Kim S. B.; Park., C.d.; Jong-Seung-Choi; KumChul Shin; Jeom Kuk Kim; Seong-Bong Kim and Chan Dong Park Chun, J.P.; Korean, O.W. and Lee, J.C. 1990. The effect of foliar application of Paclobutrazol on the vegetative growth, fruit quality and storage behaviors of 'Okubo' Peach (Prumus persica L Batsch.), J. Korean soci. Hort. Sci.,; 31: 135-14.

[6] Chun, J. P; Lee. J.C, 1989. The effect of foliar application of Paclobutrazol on vegetative growth, Fruit quality and storage behaviour of Okubo Peach trees Abstracts of communicated papers, Horticultural Abstracts, Korean Society for Horticultural Science 7: 126-127 Presented at the 27th meeting of the Korean Society for Horticultural Science held at kyung Hee University 11 Feb.1989.

[7] Curry, E.A. and Williams. M.W. 1983. Promalin or GA3 increase pedicels and Fruit Length and leaf size of' Delicious" Apples treated with Paclobutazol, Hort Sci. 18:214-215.

[8] COUTURE, R.M. 1982, PP333: a new experimentalplant growth regulator from ICI. Proc Plant Growth Regu Soc Am 9: 596.

[9] DALZIOL J; D.K LAWRENCE, 1984. Biochemical and biological effects of kaurene oxidase inhibitors, such as paclobutrazol. In R Menhenett, DK Lawrence, eds, Biochemical Aspects ofSynthetic and Naturally Occurring Plant Growth Regulators, Monograph 11. British Plant Growth Regulation Group, Wantage, England, pp 43-57

[10] EI- Khoreiby, A.M.; Unrath, C.R. and Lehman, L.J. 1990. Paclobutrazol spray timing Influence Apples green growth. Hort. Sci., 24: 310-312.

[11] E.I. Otmani.; Jabri, K and Sedhi, M. 1992. Paclobutrazol effect on devlopment on Greenhouse and growth banana: a 2 year assessment. Acta Hortic.; 196: 8996

[12] Elfving, D.C. Chu, C.L. Lougheed, E.C. and Cline, R.A. 1987. Effected of Daminozide and Paclobutrazol treatment of fruit ripening and storage behaviors of McIntosh' Apples, J. Amero Soci. Hort. Sci. 112: 910915.

[13] Elfving D.C.; Lougheed, E.C.; Chu, C.L. and Cline, R.A. 1990. Effects of Daminozide Paclobutrazol and Uniconazole treatments on' Mclntosh' Apples at harvest and following storage, J Amer Soci. Hort. Hot.Sci., 115: 750-756.

[14] Embree, G.C.; Craing, W.F. and Forsyth, F.R. 1987. Effects of Daminozide, Chlormequat, and paclobutrazole on growth and fruiting of 'clapp's favourite'Pear. Hort. Sci.; 22:55-56.

[15] Facteau, T.J. and Chestnut, N.E. 1991. Growth fruiting, flowering and fruit Quality Sweet Cherries treaded with Paclobutrazol, Hort. Sci, 26: 276-27 Forlani, M. and Coppola, V. 1992. Use of two growth regulators on grape (Cvs. Paclobutrazol and S 3307. Vignevini. 19:39-52

[16] George, A. P. Lioyd, J. and Nissen, R.J. 1992. Effects of hydrogen cyn Paclobutrazol and pruning date on dormancy release of the low chill Peach Cvs Florida prince in subtropical Australia. Ausralian J of Exp. Agric. 32:89-95.

[17] Gilffilan, I.M. and Lows, S.J. 1985. Fruit colour improvement in Satsuma's with Paclobutrazol and ethephon preliminary studies. Citrus and Subtropical Fruit Journal.621: 4-5

[18] Greene, D. W. 1989. Effect of Paclobutrazol and analogs on growth, yield, fruit quality and storage potential or Delicious 'apples. J. Am soc. Hort. Sci. 116:807-812

[19] Greene, D.W.; Murray, J. 1983. Effects of Paclobutrazol (PP333) and analogs on growth, fruit quality and storage potential of 'Delicious apples' proc. Xth anu. Meeting Plant growth Regulator Society of America, 1983-207-212 East Lansing, USA, PGR Society of America.

[20] Huang, W.D. and Shen, T.I. 1987. The effects of PP 333 (Paclobutrazol) on the growth of seedling of Pyrus betulaefolia Bge. and on the growth and fruiting of Yali pear (P.breschnederi cv. Yali) Acta Hortic. 14: 223-231.

[21] Khader, S.E.S.A. 1990. Orchard application of Paclobutrazol on ripening. Quality and storage of Mango fruits. Scientia. Hort. 41: 329-335. 
Kulkarni, V.J. 1988 a. Chemical control of tree vigour and promotion of flowering and Fruiting in mango (Mengifera indica L.) using paclbutrazol. J. Hort Sci. 63: 557-566.

[22] Martin DN, Proebsting WM, Hedden, P.1997. Mendel's dwarfing gene: cDNAs from the Le alleles and the function of the expressed proteins. Proc Natl Acad Sci USA 94:8907-8911.

[23] Kulkarni V.J. 1989. Tree vigor control in mango IIIrd International Mango Symp. Darwin, Australia, 25 29 September, 189, p.37. Phinney BO, West CA, Ritzel MB, Neely PM, 1957. Evidence for gibberellinlike substances from flowering plants. Proc Natl Acad Sci USA 43:398-404.

[24] WILLIAMS, M.W; U. EDGERTON 1983. Vegetative growth control of apple and pear trees with ICI PP333 (paclobutrazol) a chemical analog of Bayleton. Acta Hortic 137: 111-1 16.

[25] WANG, S.Y; G.L. STEFFENS, M. FAUST, 1986. Effect of paclobutrazol on cell wall polysaccharide composition of apple tree. Phytochemistry 25: In pr.

[26] Yabuta T, 1935. Biochemistry of the "bakanae" fungus of rice. Agriculture and Horticulture 10:17-22. XXXIV. Isolation of gibberellins and their properties. Bull Agric Chem Soc Jpn 19:267-277.

[27] QUINLAN JD, PJ RICHARDSON, 1984. Effect of paclobutrazol (PP333) on apple shoots growth. Acta Hortic. 146: 105-1 10

[28] Radley M, 1956. Occurrences of substances similar to gibberellic acid in higher plants. Nature 178:10701071.

[29] Scott, I.M, 1990. Plant hormone response mutants. Physiol Plant 78:147-152.

[30] STEFFENS GL, JK BYUN, SY WANG 1985. Controlling plant growth via the gibberellin biosynthesis system. I. Growth parameter alterations in apple seedlings. Physiol Plant, 63: 163-168

[31] STINCHCOMBE GR, E COPAS, RR WILLIAMS, G ARNOLD 1984. The effect of paclobutrazol and daminozide on the growth and yield of cider apple trees. J Hortic Sci. 59: 323-32

Citation: Ashok Kumar, et.al, " Chemical Control of Vegetative Growth of Mango Cvs.Dashahari, Langra, Chuasa and Fazri through Paclobutrazol Application", International Journal of Forestry and Horticulture (IJFH), vol. 5, no. 2,pp.36-43, 2019. Available: DOI: http://dx.doi.org/10.20431/2454-9487.0502004

Copyright: (c) 2019 Authors. This is an open-access article distributed under the terms of the Creative Commons Attribution License, which permits unrestricted use, distribution, and reproduction in any medium, provided the original author and source are credited. 